\title{
PENERAPAN METODE REWARD DAN PUNISHMENT UNTUK MENGEMBANGKAN KEMAMPUAN EMOSIONAL DASAR ANAK DI PAUD DARUL AMANI KOSAMBI
}

\author{
Eka Sulistyawati ${ }^{1(*)}$, Joni Tesmanto $^{2}$ \\ Universitas Panca Sakti Bekasi, Indonesia ${ }^{12}$ \\ ekasulistyawati@gmail.com ${ }^{1}$, jonitesmanto@gmail.com²
}

\begin{tabular}{ll}
\hline & \\
Received: & 23 Agustus 2021 \\
Revised: & 23 September 2021 \\
Accepted: & 23 Oktober 2021
\end{tabular}

\begin{abstract}
Anak adalah buah hati dan sekaligus menjadi investasi orang tua di masa

mendatang. Ketika di pendidikan formal seperti TK atau PAUD, terkadang perilaku anak seringkali berlebihan. Oleh sebab itu, alternatif yang diberikan adalah metode reward dan punishment. Metode ini bertujuan untuk mendisiplinkan dan mendidik anak dengan kasih sayang bukan untuk menakut-nakuti atau mengancam mereka. Pendekatan penelitian yang akan digunakan adalah pendekatan kualitatif studi kasus. Penelitian ini akan menggambarkan tentang penggunaan reward dan punishment dalam perkembangan kemampuan dasar emosional anak usia dini. Penelitian ini merupakan suatu penelitian yang dilakukan terhadap suatu kesatuan sistem. Kesatuan ini dapat berupa program, kegiatan, peristiwa atau sekelompok individ yang terikat oleh tempat, waktu atau ikatan tertentu. Sebelum pelaksanaan wawancara peneliti melakukan pendekatan melalui perkenalan dan pembicaraan bebas sampai pada titik masalah tentang metode pemberian reward dan punishment dalam kegiatan pembelajaran di TK tesebut. Penerapan reward di PAUD Darul Amani Kosambi pada kelompok B yang diobservasi dan diteliti peneliti dengan cara menerapkan reward dengan sistem diagram bintang. Dimana bagi anak yang pada setiap harinya melakukan kegiatan, mau diingatkan, berbagi dengan teman, dan melakukan suatu kegiatan kebiasaan maka anak tersebut akan mendapatkan reward berupa sebuah bintang atau dengan memberi pujian, acungan jempol, sesekali mereka juga diberi hadiah berupa baris di depan nomer pertama, duduk dibangku depan, dan lain-lain. Sedangkan punishment adalah hukuman bagi mereka agar mereka jera dan tidak melakukan kesalahan yang sama.
\end{abstract} Accepted: 23 Oktober 2021

Keywords: Metode Reward, Punishment, PAUD

How to Cite: Sulistyawati, E. \& Tesmanto, J. (2021). Penerapan Metode Reward Dan Punishment Untuk Mengembangkan Kemampuan Emosional Dasar Anak Di PAUD Darul Amani Kosambi. Research and Development Journal of Education, 7 (2), 511-517.

\section{INTRODUCTION}

Pendidikan nasional berfungsi mengembangkan kemampuan dan membentuk watak serta peradaban bangsa yang bermartabat dalam rangka mencerdaskan kehidupan bangsa. Pendidikan bertuju mengembangkan potensi peserta didik agar menjadi manusia yang beriman dan bertakwa kepada Tuhan Yang Maha Esa, berakhlak mulia, sehat, berilmu, cakap, kreatif, mandiri, dan menjadi warga Negara yang demokratis serta bertanggung jawab. Hal tersebut tertuang dalam UU RI (Nomor 20 tahun 2003) tentang Sistem Pendidikan Nasional, tujuan pendidikan Bab II pasal 3 yaitu tujuan membangun manusia holistik. 
Pendidikan nasional harus dapat mengembangkan seluruh aspek potensi manusia secara keselurahan. Proses pendidikan harus mampu membentuk manusia yang utuh dan cakap dalam menghadapi dunia yang penuh tantangan dan dinamis serta mempunyai kesadaran spiritual. Fungsi terpenting pendidikan adalah menghasilkan manusia yang terintegrasi, yang mampu menyatu dengan kehidupan sebagai satu kesatuan. Pendidikan sangat luas cakupannya, diantaranya pendidikan di rumah. Pendidikan di rumah, anak akan berpusat pada org tua dan keluarga. Pendidikan di sekolah, anak akan berpusat pada guru dan teman-temannya. Dan pendidikan lingkungan, anak berpusat pada masyarakat.

Pendidikan formal sudah sejak lama diselenggarakan di Indonesia. Pendidikan tersebut sudah menjalar bagaikan jamur yang merambat. Pendidikan formal meliputi PAUD dan TK. Pendidikan formal dapat membantu masyarakat untuk dapat memberikan pendidikan dan perhatian secara utuh pada anak-anaknya untuk masa depannya. Anak adalah buah hati orang tua. Anak adalah investasi bagi orang tua dan negara yang sangat berharga. Karena pada kenyataannya setiap orang tua dari kalangan manapun mereka berasal sudah dapat dipastikan akan berbuat apa saja demi kebahagiaan anak-anaknya. Untuk itu, sangatlah bijak apabila kita sebagai orang dewasa, apakah orang itu orang tua di rumah, guru di sekolah dan orang tua dewasa lain yang berada di sekitar anak dapat berbuat dan memperlakukan anak sebagai "miniature" orang dewasa, tetapi dapat memperlakukannya sebagai "makhluk kecil" yang diyakini memiliki potensi untuk berkembang. Jadi, bagaimana anak itu akan berhasil dan sukses tergantung bagaimana stimulus dari orang tua, negara dan lingkungan masyarakat

Anak usia dini adalah sosok individu yang sedang berada dalam proses perkembangan Perkembangan merupakan proses perubahan perilaku dari matang merah matang gat sederhana menjadi kompleks, suatu proses solusi manusia dan ketergantungan menjadi makhluk dewasa yang mandiri. Perkembangan adalah suatu proses perubahan anak belajar menguasai tingkat yang lebih tinggi dari aspek-aspek: gerakan, berpikir, perasaan, dan interaksi baik dengan sesama maupun dengan benda-benda dalam lingkungan hidupnya (Lestari dan Prima, 2018). Membangun karakteristik anak ibarat membangun sebuah tenda yang mempunyai beberapa tongkat sebagai penyangganya. Jika semakin tinggi tongkat-tongkat penyangganya, semakin tinggi pula tenda-tenda itu berdiri.

Dalam kurikulum PAUD ditegaskan bahwa program pembelajaran meliputi bidang pengembangan pembiasaan merupakan kegiatan yang dilakukan secara terus menerus dan ada dalam kehidupan sehari-hari anak, sehingga menjadi pola pengembangan yang baik. Dari pembiasaan tersebut kompetensi dasar yang diharapkan dicapai oleh anak yaitu anak mampu melakukan ibadah, terbiasa mengikuti aturan, dapat hidup bersih dan mulai membedakan benar dan salah, serta terbiasa berperilaku terpuji.

Lingkungan luar yang baru diketahui oleh anak, dengan teman-teman yang bertambah banyak dan berbagai jenis ragam anak yang memiliki karakter yang berbedabeda. Tidak sedikit dari anak-anak tersebut memiliki karakter yang kurang baik yang dapat dilihat langsung oleh anak dalam bergaul. Lingkungan luar tempat anak bertambah banyak teman, merupakan salah satu faktor yang mempengaruhi belajar anak dalam menumbuh kembangkan semua aspek perkembangan anak.

Kenyataan yang harus dihadapi guru PAUD Darul Amani dalam kegiatan pembelajaran adakalanya mengalami permasalahan yang dihadapi dalam mengajar yaitu dalam mengkondisikan peserta didik yang memiliki beberapa karakteristik dan sifat yang berbeda-beda. Begitu pula dengan keadaan yang harus dihadapi oleh guru PAUD Darul Amani Kosambi yang berada di dekat jalan raya dan anak-anaknya rata-rata dari kalangan polisi. Kebanyakan anak polisi kadang susah diatur dan memiliki banyak perilaku yang tidak diinginkan, tetapi tidak semua anak berperilaku negatif. Oleh karena itu para pendidik perlu memperbaiki perilaku anak-anaknya agar dapat memenuhi kompetensi 
dasar bidang pengembangan pembiasaan berupa kestabilan emosional anak dalam kegiatan pembelajaran dalam mewujudkan proses pembelajaran dan hasil yang optimal.

Dengan melihat perilaku anak dan berusaha untuk memperbaiki perilaku atau emosional anak yang berbeda-beda, para pendidik akan berusaha bagaimana cara menghadapi atau merubah metode pembelajaran agar kegiatan dapat berjalan dengan baik. Untuk mengatasai hal tersebut, para pendidik PAUD Darul Amani memiliki strategi tersendiri di antaranya dengan menggunakan metode reward dan punishment berupa diagram bintang dan time out untuk memperbaiki perilaku buruk yang dilakukan anak dalam kegiatan pembelajaran. Sedangkan di PAUD Darul Amani Kosambi menggunakan strategi dengan menggunakan metode reward berupa hadiah kecil seperti bentuk bintang, permen dan punishment berupa maju ke depan seperti menyanyi, berdoa, dan bersyair.

Dengan metode tersebut diharapkan dapat memperbaiki perilaku buruk anak dan dapat membiasakan anak untuk berperilaku positif dalam melakukan segala sesuatu secara terus menerus dalam kehidupan sehari-hari. Bukan hanya dengan memperbaiki sikap buruknya saja dalam kehidupan sehari-hari. akan tetapi perhatian, nasehat, dan stimulus dari orang dewasa, pendidik, dan orang-orang yang ada di dekatnya.Orang tua dan orang dewasa adalah figur dari anak, bagaimana cara kita memberi contoh bagi anakanak baik atau buruk tergantung dari orang tua dan orang dewasa itu sendiri. Anak tidak akan meniru sifat dan sikap dari luar atau orang lain, jika kita sebagai orang tua dan pendidik memberikan stimulus, pengertian, dan perhatian penuh kepada anak tentang apa sebenarnya yang diinginkan oleh anak. Semua anak dilahirkan suci dan tidak ada noda, tetapi tergantung kita sebagai orang tua dan orang dewasa dalam memberikan stimulus dan berperilaku yang baik kepada anak.

\section{METHODS}

Pendekatan penelitian yang akan digunakan adalah pendekatan kualitatif studi kasus. Penelitian ini akan menggambarkan tentang penggunaan reward dan punishment dalam perkembangan kemampuan dasar emosional anak usia dini. Penelitian ini merupakan suatu penelitian yang dilakukan terhadap suatu kesatuan sistem. Kesatuan ini dapat berupa program, kegiatan, peristiwa atau sekelompok individ yang terikat oleh tempat, waktu atau ikatan tertentu. Studi kasus adalah suatu penelitian yang diarahkan untuk menghimpun data. mengambil makna, memperoleh pemahaman dari suatu kasus. Kasus sama sekali tidak mewaliki populasi dan tidak dimaksudkan untuk memperoleh kesimpulan dari populasi. Tiap kasus bersifat unik atau memiliki karakteristik sendiri yang bebeda dengan kasus yang lainnya.

Sampel yang digunakan yaitu siswa-siswi PAUD Darul Kosambi. Sedangkan populasi dalam penelitian ini adalah :

1. Subyek penelitiannya adalah siswa kelompok A PAUD Darul Amani yang berjumlah 34 siswa dan kelompok yang berjumlah 34 siswa.

2. Kepala sekolah PAUD NDarul Amani Kosambi.

3. Guru kelas PAUD Darul Amani Kosambi

Penelitian dilaksanakan di PAUD Darul Amani Kosambi Kabupaten Tangerang dan dilaksanakan pada Bulan April 2021Metode pengumpulan data yang digunakan dalam penelitian ini ada 2 metode yaitu:

1. Library Research yaitu dengan cara membaca buku-buku yang berkaitan dengan pengembangan anak dan permasalahan anak usia dini yang hendak diteliti

2. Field research yaitu dalam hal ini penulis melakukan kegiatan 
Dalam analisis ini penulis mula-mula membaca hasil catatan observasi dan wawancara untuk pengumpulan data. Setelah data terkumpul dilakukan proses penyederhanaan. abstraksi (pemisahan data) dan transformasi (perubahan data). Dari data yang diperoleh kemudian dideskripsikan untuk melakukan penarikan kesimpulan dan pengambilan tindakan. Kemudian setiap kesimpulan yang ditetapkan akan terus menerus diverivikasikan hingga benar-benar diperoleh konklusi yang valid dan kokoh.

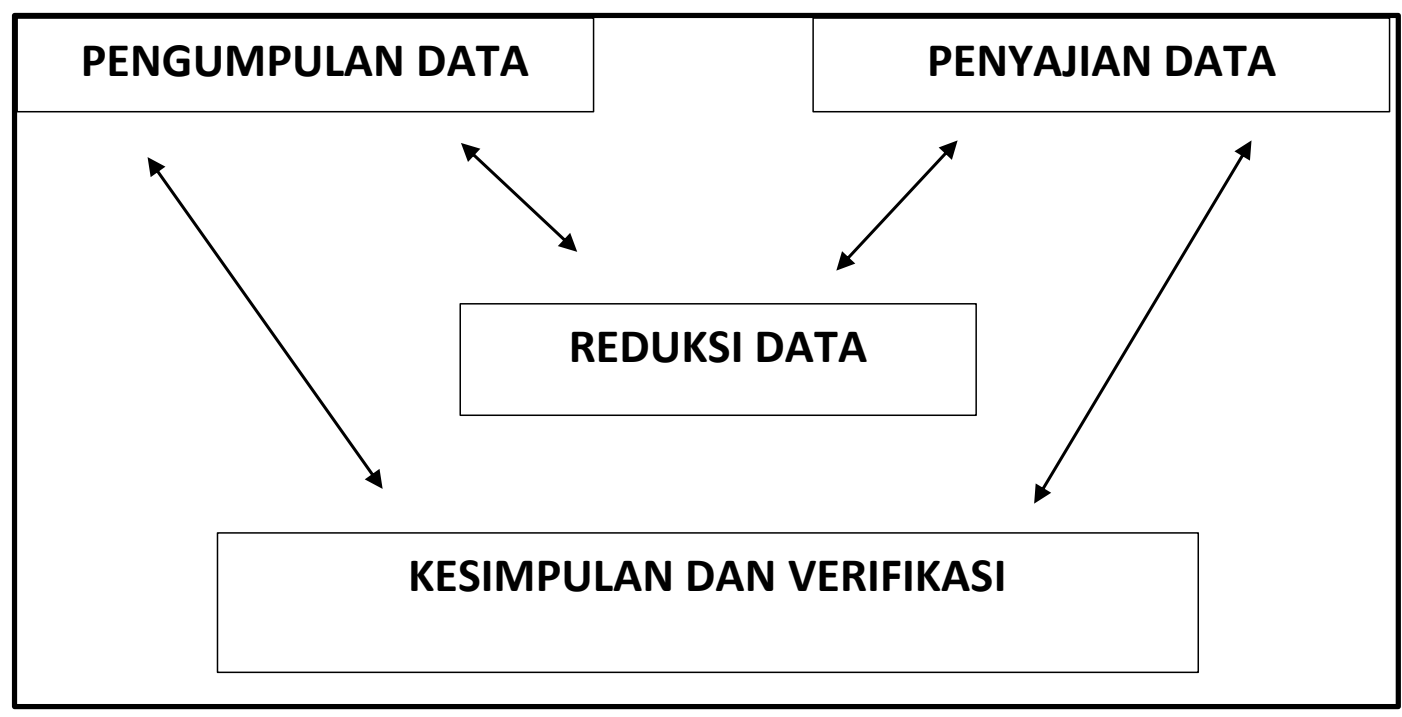

\section{Gambar 1.}

Komponen Analisis Data Model Interaktif (Interactive Model)

\section{RESULTS \& DISCUSSION}

Penelitian diawali dengan permohonan ijin dari kepala sekolah dahulu setelah mendapat ijin dari kepala sekolah, peneliti langsung melakukan observasi di kelas yang akan diteliti yaitu kelompok B, yang dilanjutkan dengan wawancara kepala sekolah, guru, dan anak didik. Adapun yang menjadi subyek penelitian terdiri dari dua kepala sekolah, dua orang guru dan dua anak didik.

Sebelum pelaksanaan wawancara, peneliti melakukan pendekatan melalui perkenalan dan pembicaraan bebas sampai pada titik masalah tentang metode pemberian reward dan punishment dalam kegiatan pembelajaran di kedua TK tesebut. Penerapan Reward di PAUD Darul Amani Kosambi pada kelompok yang diobservasi dan teliti peneliti pada kelompok B yaitu dalam kelas guru menerapkan reward dengan sistem diagram bintang. Dimana bagi siswa yang pada setiap harinya melakukan kegiatan, mau diingatkan, berbagi dengan teman, dan melakukan suatu kegiatan kebiasaan maka siswa tersebut akan mendapatkan reward berupa sebuah bintang atau dengan memberi pujian, acungan jempol, sesekali mereka juga diberi hadiah berupa baris di depan nomer pertama, duduk dibangku depan, dan lain-lain.

\section{Reward}

Reward adalah ganjaran (Kusyairy dan Culo, 2018), hadiah, penghargaan atau imbalan. Dengan menggunakan reward, kondisi kelas dapat teratasi dan kegiatan anakanak dapat terlaksana dan berjalan dengan lancar. Reward memberi semangat bagi anak untuk melakukan kegiatan dan anak yang berprilaku tidak baik sehingga menjadi baik. 
Seperti penuturan Kepala Sekolah sebagai berikut:

"Reward adalah hadiah untuk anak yang memiliki prestasi atau anak yang mau melakukan kegiatan".

Hal tersebut sesuai dengan pernyataan guru:

"Reward merupakan sesuatu yang bisa dirasakan dan dilihat oleh anak didik sebagai penghargaan atas apa yang telah dilakukan oleh anak, walaupun bukan berbentuk benda saja, seperti: pujian, acungan jempol, memberi tepuk, memberi nyanyian atau yang lainnya, sehingga anak menjadi giat lagi untuk melakukan kegiatan".

Reward di PAUD Darul Amani berupa barang, dimana sebelum guru memberikan hadiah kecil berbentuk barang seperti pensil, penghapus. permen atau yang lain-lainnya, dewan guru menggunakan diagram bintang, setiap anak melakukan kegiatan dengan bagus, seperti berdoa, mengerjakan tugas sampai selesai, tidak mengganggu temannya, maka akan diberi sebuah bintang, setelah bintang-bintang itu jumlahnya banyak, maka mereka akan menukarnya dengan hadiah-hadiah kecil.

Dengan penerapan reward diharapkan dalam melakukan kegiatan belajar mengajar semua berjalan dengan lancar, kemudian anak-anak dapat memahami tentang rasa sosial kepada semua orang, tidak egois, menang sendiri. Reward diharapkan dapat pula menstabilkan sosial emosional setiap anak, guru dan orang-orang yang ikut terlibat didalam pembelajaran anak.

\section{Punishment}

Punishment adalah hukuman (Vhalery, 2021), ganjaran, peringatan untuk seseorang yang telah melakukan suatu kesalahan. Bagaimana punishment itu diterapkan sesuai dengan kondisi suatu tempat atau organisasi yang didalamnya menggunakan sistem punishment untuk para anggotanya. Penerapan Punishment di PAUD Darul Amani Kosambi pada kelompok yang diobservasi dan diteliti peneliti pada kelompok B yaitu dalam kelas guru menerapkan punishmen dengan sistem memisahkan anak dengan kegiatan bermain dengan teman yang lainnya serta memberi kegiatan bermain yang tidak sesuai dengan keinginannya, sehingga anak dapat berfikir kalau melakukan kesalahan atau melakukan sesuatu yang dapat merugikan orang lain/teman maka tidak akan dapat memperoleh apa yang dia inginkan.

Berikut penuturan dari Kepala Sekolah "Punishment merupakan suatu hukuman yang diberikan kepada anak atau orang yangmelakukan kesalahan.

Hal tersebut sesuai dengan pernyataan guru.

"Tindakan yang diberikan kepada anak didik karena kesalahan yang dilakukan pada suatu kegiatan misalnya: anak disuruh menghafal nama-nama malaikat, nama hewan”.

Dengan penerapan punishment yang bersifat mendidik dan memberi jera pada anak tetapi tidak membahayakan anak, punishment akan menjadi suatu acuan bahwa pemberian punishment yang mendidik akan membuat anak jera, membuat kegiatan belajar mngajar berjalan sesuai dengan harapan guru, anak dan orang tua murid. 


\section{Temuan Penelitian}

Dalam pemberian reward dan punishment di PAUD Darul Amani, ada anak yang merasa bahwa reward dan punishment sebagai ancaman baginya, ada juga yang menganggap bahwa itu adalah penyemangat. Dengan kata lain, anak-anak menjadi semangat untuk melakukan kegiatan sampai anak bisa mendapatkan reward itu

Penerapan dalam pemberian reward dan punishment hendaknya yang mendidik, dimana penerimaan reward dan punishment pada setiap anak itu berbeda-beda, ada yang menganggap reward dan punishment adalah ancaman bagi anak untuk melakukan sesuatu yang tidak mereka inginkan. Tetapi disisi lain, pemberian reward dan punishment kepada anak usia dini yang sesuai dengan umur, penalaran dan cara menyampaikan dengan bahasa yang dapat diterima anak maka akan menjadi penyemangat dan melatih kedisiplinan anak dalam mengerjakan kegiatan baik di sekolah atau diluar sekolah.

Dari penyampaian reward dan punishment yang bisa diterima anak, maka dapat melatih kemampuan emosional anak dalam keseharian, yang tadinya anaknya tidak mau diingatkan setelah mendapat reward si anak akan merasa bahwa kegiatan yang dilakukannya dengan baik akan mendapat perhatian dari orang-orang disekelilingnya dan apabila si anak melakukan yang tidak disukai maka dia akan merasa malu dan tidak ingin melakukannya lagi. Untuk itu, pendidikan dan cara menstimulus anak hendaknya melihat kondisi anak, waktu, keadaan tempat, dan cara menyampaikannya. Kekerasan yang berkembang dalam pendidikan, tidak hanya menghasilkan kultur kekerasan, tetapi juga bisa menghasilkan sikap-sikap negatif yang akan mewarnai pola sikap dan pola tindak siswa.

\section{CONCLUSION}

Berdasarkan kajian yang telah dilakukan dapat disimpulkan bahwa metode reward dan punishment dalam mengembangkan kemampuan emosional anak usia dini yang dilakukan oleh PAUD Darul Amani Kosambi berlangsung dengan baik walaupun keduanya memiliki metode yang berbeda-beda. Metode ini didukung dengan baik oleh orang tua murid. Mereka juga menanamkan metode reward dan punishment untuk anaknya di dalam rumah.

Manfaat dari penerapan metode reward dan punishment untuk anak yaitu dapat melatih anak untuk belajar sabar, bergantian, bergotong royong, menahan amarah dan emosi serta balajar kasih sayang terhadap semua orang, baik orang dewasa atau anak seusianya. Untuk sekolah PAUD Darul Amani Kosambi itu sendiri yaitu adanya penguatan metode pembelajaran berupa reward dan punishment. Untuk guru, adanya metode pembelajaran dari dan oleh guru yang menerapkan dan menitik beratkan berupa penguatan reward dan punishment sehingga guru dapat mengkondisikan kelas.

Adanya dukungan dari orang tua dan guru untuk menyuruh siswa melaksanakan tugasnya, hal ini mendukung kemampuan mereka. Guru dan orang tua murid juga dapat bekerjasama dalam mewujudkan kebiasaan anak dalam hal kebaikan dan kedisiplinan serta melatih kemampuan emosional anak sejak dini. Dengan adanya kesamaan antara perintah di sekolah dan di rumah, anak tidak akan bingung mau mengikuti peraturan guru atau orang tua di rumah. Kesabaran para dewan guru dalam mendidik, mengasuh, danmemperhatikan anak didiknya dengan baik dan penuh kasih sayang membuat anak menjadi semangat, betah untuk selalu berangkat ke sekolah.

Adapun evaluasi yang dilakukan di PAUD Darul Amani Kosambi yaitu cara guru untuk meyakinkan anak dalam menggunakan reward dan punishment dengan sangat baik, 
seperti tidak lupa dengan pembuatan bintang atau hadiah lainnya serta memberi hukuman yang membuat anak jera sehingga tidak mengulangi perbuatan yang salah lagi.

\section{REFERENCES}

Kusyairy, U., \& Culo, S. (2018). Meningkatkan Hasil Belajar Peserta Didik Melalui Pemberian Reward And Punishment. JPF (Jurnal Pendidikan Fisika) Universitas Islam Negeri Alauddin Makassar, 6(2), 81-88.

Lestari, P. I., \& Prima, E. (2018, December). Permainan congklak dalam meningkatkan perkembangan kognitif anak usia 5-6 tahun. In Seminar Ilmiah Nasional Teknologi, Sains, dan Sosial Humaniora (SINTESA) (Vol. 1, No. 1).

Vhalery, R. (2021). Self-Reward dan Self-Punishment Untuk Pengelolaan Uang Saku Dan Penggunaan Aplikasi Fintech. Duconomics Sci-meet (Education \& Economics Science Meet), 1, 1-7. 